\title{
Time for concrete casting: a new paradigm
}

\section{Tempo de lançamento do concreto: um novo paradigma}
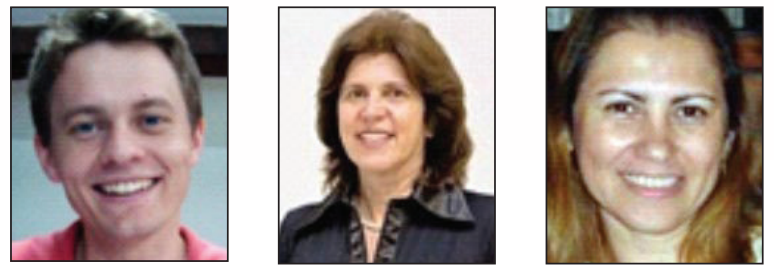

A. B. ROHDEN a abrcivil@gmail.com

D. C. C. DAL MOLIN dmolin@ufrgs.br

G. L. VIEIRA c geilma.vieira@gmail.com

\begin{abstract}
The Brazilian standard NBR 7212 states that the time of transporting the concrete between the start of mixing should be less than 90 minutes so that by the end of the discharge is a maximum of 150 minutes. Yet often, in construction, concrete is used after this period. In order to investigate the behavior of concrete after setting time of cement was cast six concrete mixtures with two types of cement. The mixtures were produced and kept fresh for six hours, adopting a procedure for maintenance of abatement by superplasticizer and agitation. The results show that of the test piece molded over six hours of maintained or increased the compressive strength average.
\end{abstract}

Keywords: start time of catching, transportation of concrete, concrete machined

\section{Resumo}

A norma brasileira NBR 7212 coloca que o tempo de transporte do concreto decorrido entre o início da mistura deve ser inferior a 90 minutos de maneira que até o fim da descarga seja de no máximo 150 minutos. No entanto muitas vezes, em obra, o concreto é utilizado após este período. Com intuito de investigar o comportamento do concreto após o tempo de pega do cimento foram moldados seis traços de concreto com dois tipos de cimento. As misturas foram produzidas e mantidas no estado fresco por seis horas, adotando-se um procedimento de manutenção do abatimento através de aditivo superplastificante e agitação. Os resultados mostram que os corpos-de-prova moldados ao longo das seis horas mantiveram ou aumentaram a resistência à compressão média.

Palavras-chave: tempo de início de pega; transporte de concreto; concreto usinado.

a Universidade Federal do Rio Grande do Sul, Departamento de Engenharia Civil, Escola de Engenharia, Núcleo Orientado para Inovação da Edificação, abrcivil@gmail.com, Rua Osvaldo Aranha, 99 - Centro, Porto Alegre, Brasil;

b Universidade Federal do Rio Grande do Sul, Departamento de Engenharia Civil, Escola de Engenharia, Núcleo Orientado para Inovação da Edificação, dmolin@ufrgs.br, Rua Osvaldo Aranha, 99 - Centro, Porto Alegre, Brasil.

c Universidade Federal do Espirito Santo, Departamento de Engenharia Civil, Centro Tecnológico, geilma.vieira@gmail.com,

Av. Fernando Ferrari, 514 - Vitória, Espírito Santo, Brasil. 


\section{Introduction}

The transportation time of concrete from the first addition of water until the beginning of its discharge at the construction site must be, according to NBR 7212:

a) fixed, so that the end of compacting does not occur after the initial setting of the cast concrete and the layers or parts adjacent to this batch;

b) under $90 \mathrm{~min}$ and fixed, so that by the end of the discharge no more than 150 minutes have elapsed, in case of using a vehicle equipped with an agitator;

c) under $40 \mathrm{~min}$ and fixed, so that by the end of the discharge no more than 60 minutes have elapsed, in case of using a vehicle without an agitator.

The transportation of pre-mixed concrete to the construction site must be undertaken as fast as possible in order to minimize the effects of stiffening and loss of workability, and to allow appropriate setting and finishing after casting. Under normal conditions, there is generally negligible slump loss during the first 30 minutes after the initial hydration of Portland cement. When the concrete is agitated at low speed or when it is periodically remixed, there may occur some slump loss with time, which does not generally cause any serious problems for the casting and setting of fresh concrete in the first 90 minutes (Mehta and Monteiro, 2008).If that time interval is exceeded, it is still possible to add plasticizers and/ or superplasticizer to recover the concrete's slump for subsequent casting and setting, as slump correction with water causes significant damage to the mechanical properties.

The workability of concrete is the property that determines the effort required to manipulate a specific amount of fresh concrete, with minimal loss of homogeneity. The term manipulate includeeesarly stage operations, such as casting, setting and finishing (Mehta and Monteiro, 2008).

The change from the fluid to the rigid state is, in general terms, defined as setting (NEVILLE, 1995). Setting is the term used to designate the stiffening of the cement paste, even though the definition of stiffening of the paste is arbitrary. According to MEHTA and MONTEIRO (1994), what causes the stiffening of the paste and, finally, its setting and hardening is the gradual loss of free water due to hydration reactions, physical adsorption on the surface of the hydration products with poor crystallinety (such as C-S-H and ettringite) and evaporation. The beginning of the setting marks the moment when the paste becomes unworkable. Consequently, the casting, compacting and finishing of the concrete become difficult after this stage.

The paste does not solidify suddenly, it needs considerable time to become totally rigid. The time necessary for the paste to totally solidify marks the end of the setting, which should not be long, so that other constructive activities can be resumed as soon as possible after the concrete casting (MEHTA and MONTEIRO, 2008).

The terms initial set and final set are used to arbitrarily describe specific states of the setting. Although in the interval between the initial and the final set, the paste acquires a certain resistance, from a practical point of view, the development of the paste's resistance is considered after the end of the setting, when the hardening starts (NEVILLE, 1995).

The standard test to determine setting times is the needle penetration test. It is done almost universally by using the Vicat apparatus. In Brazil, the testing method is prescribed by the NBR NM 65 (2002). The initial set time is designated as the time elapsed between the moment water is added to the cement and the moment when the Vicat needle, with standard diameter and mass, penetrates the standard consistency paste and stops $1 \mathrm{~mm}$ from the bottom of a particular mold. Therefore, for each cement, it is necessary to determine the water content of the paste that produces the standard slump (NBR NM 67, 1998). The final set time is defined as the time interval between the pouring of water into the cement and the first of three successive readings equal or higher than $38 \mathrm{~mm}$, done in the normal consistency paste, using a Vicat needle (SILVA, 2007).

Specification norms establish the acceptable limits for each Portland cement designation. NBR 5733 - CPV, NBR 5735 - CPIII, NBR 5736 - CPIV and NBR 11578 - CPII establish that the initial set time should be equal to or over1 hour.

The reactions between cement and water are the basic

Figure 1 - Schematic representation of the notions of the percolation theory according to ACKER (1988) apud SILVA (2007)

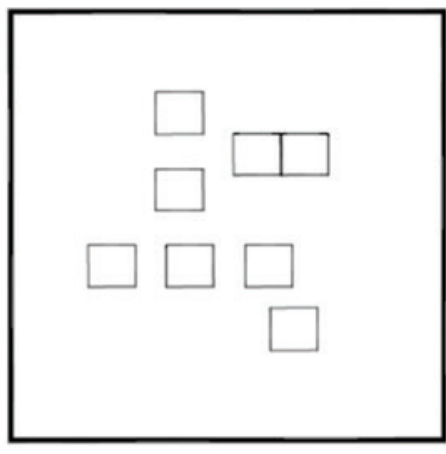

a) Isolated Events

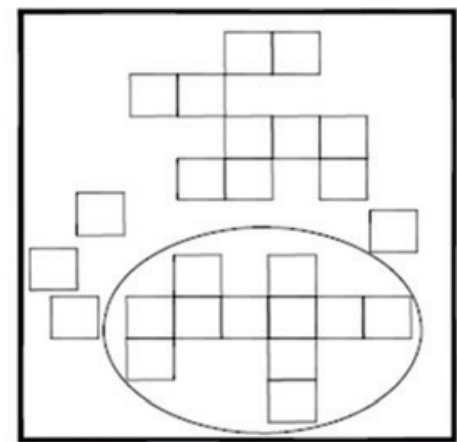

b) Forming of Amass

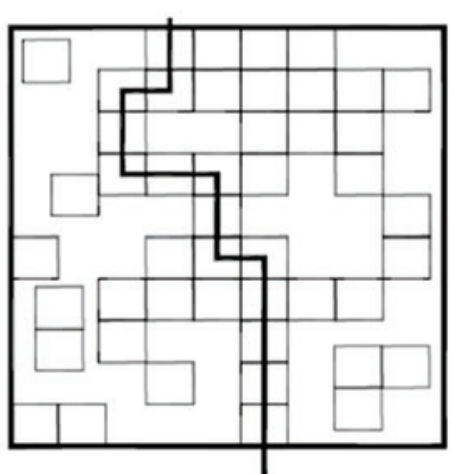

c) Percolation Threshold 


\section{Table 1 - Chemical characterization of the cements used}

\begin{tabular}{|ccccc}
$\begin{array}{c}\text { Evaluated } \\
\text { charcateristics } \\
\text { (\% of the mass) }\end{array}$ & $\begin{array}{c}\text { Types of Portland cement } \\
\text { (manufacturer) }\end{array}$ & $\begin{array}{c}\text { NBR 5736/91 } \\
\text { requirements } \\
5736 / 91\end{array}$ & $\begin{array}{c}\text { CP V - ARI } \\
\text { (manufacturer) }\end{array}$ & $\begin{array}{c}\text { NBR 5733/91 } \\
\text { requirements }\end{array}$ \\
$\mathrm{MgO}^{\mathrm{SO}}$ & 4.39 & $\leq 6.50$ & 3.01 & $\leq 6.50$ \\
Loss on ignition & 2.12 & $\leq 4.00$ & 4.26 & $\leq 4.50$ \\
Free CaO & 3.74 & $\leq 4.50$ & 3.90 & - \\
Insoluble residue & 0.80 & - & - & - \\
\hline
\end{tabular}

causes of concrete setting, even though, for several reasons, the setting time of the concrete does not coincide with the setting time of the cement used in the concrete. The phenomena of stiffening, setting and hardening are physical manifestations of the progressive hydration reactions of the cement (SILVA, 2007).

In practical terms, the initial set time gives an idea of the time available to manipulate the concrete made with particular cement. However, the result is not very precise, since the test is done under standardized conditions, while on the field, the concrete suffers the influence of uncontrolled factors, such as temperature and relative air humidity, as well as the addition of chemical additives, which can alter the set time (SILVA, 2007).

The percolation theory by ACKER (1988) apud SILVA (2007) allows the simulation of cement hydration and a description of the setting phenomenon. The solid grains of cement, isolated in the suspension phase, start to come into contact with each other as hydration products start forming around those grains. The establishment of these mechanical links between the grains occurs in a random and discontinuous manner in the volume, and at the sub- sequent stage, they start forming amass, continuous subgroups of mechanically connected grains. The appearance of the first continuous path going through the group constitutes the percolation threshold, which is the first continuous path of grains mechanically connected, joining one face of the volume to the opposing face (Figure1) (SILVA, 2007).

When the setting time has ended and the hydration process and formation of the first amass start, the remix of the concrete necessarily includes the breaking of the first crystals derived from the hydration process. Would this fact damage the mechanical properties? Could this material be used with a structural function?

Vieira (2008) investigated the influence that micro fissures caused by early loading have on the mechanical properties of concrete. Microscopy tests detected the recovery of micro fissures verified in samples of concrete produced with CPV ARI and submitted to pre-loads of $75 \%$ of their breaking load, at 7 days. The recovery of the micro fissures corroborates the theory that there occurs autogenous healing, cracking of weaker crystalsand hydration of remaining resistant compounds, proposed by that study.

\section{Table 2 - Physical characterization of the cements used}

\begin{tabular}{|c|c|c|c|c|}
\hline \multirow[b]{2}{*}{$\begin{array}{c}\text { Characteristics } \\
\text { evaluated }\end{array}$} & \multicolumn{4}{|c|}{ Types of Portland cement } \\
\hline & $\begin{array}{c}\text { CP IV } \\
\text { (manufacturer) }\end{array}$ & $\begin{array}{l}\text { NBR 5736/91 } \\
\text { requirements }\end{array}$ & $\begin{array}{c}\text { CP V - ARI } \\
\text { (manufacturer) }\end{array}$ & $\begin{array}{l}\text { NBR 5733/91 } \\
\text { requirements }\end{array}$ \\
\hline Specific mass $\left(\mathrm{cm}^{3} / \mathrm{g}\right)$ & 2.80 & - & 3.05 & - \\
\hline Heat expansion (mm) & 0.0 & $\leq 5.0$ & 0.0 & $\leq 5.0$ \\
\hline \multirow{2}{*}{ Set time (h:mm) } & $04: 12$ & $\geq 01: 00$ & $02: 55$ & $\geq 01: 00$ \\
\hline & 05:21 & $\leq 12: 00$ & 04:35 & $\leq 10: 00$ \\
\hline Normal slump (\%) & 34.9 & - & - & - \\
\hline Blaine fineness $\left(\mathrm{cm}^{2} / \mathrm{g}\right)$ & 4306 & - & 4970 & $\geq 3000$ \\
\hline Sieve residue \#200mm (\%) & 1.1 & $\leq 8.0$ & 0.16 & $\leq 6.0$ \\
\hline Sieve residue $\# 3250 \mathrm{~mm}(\%)$ & 5.1 & - & 1.44 & - \\
\hline
\end{tabular}




\section{Table 3 - Composition of the mixes and water/cement ratios}

\begin{tabular}{|c|c|c|c|c|c|}
\hline \multirow{2}{*}{$\begin{array}{c}\text { Mix } \\
\text { proportion }\end{array}$} & \multicolumn{3}{|c|}{ Unit mix proportion } & \multicolumn{2}{|c|}{ water/cement ratio } \\
\hline & Cement & Fine aggregate & Coarse aggregate & CPIV & CPV \\
\hline $1: 2.5$ & 1 & 0.86 & 1.65 & 0.39 & 0.31 \\
\hline $1: 4$ & 1 & 1.65 & 2.35 & 0.45 & 0.43 \\
\hline $1: 5.5$ & 1 & 2.45 & 3.06 & 0.52 & 0.50 \\
\hline
\end{tabular}

\subsection{Justification}

In view of the stiffening mechanism of the cement and concrete paste and the capacity of recovery of its structure even when submitted to loads already in the hardened state, this study aims to investigate the viability of using the concrete after the cement set time. Hence, this initial study sought to characterize the compressive strength of concrete mixed over a period of six hours.

Given the importance of the slump of the mix for the processes of concrete casting and finishing, in this study, the slump was maintained at $100 \pm 20 \mathrm{~mm}$ over time, by using a superplasticizer.

\section{Materials and experimental program}

\subsection{Materials used}

\subsubsection{Cement}

With the aim of contemplating different test situations, two types of cement with very different chemical compositions and initial resistance were used. One was a high initial strength Portland cement (CPV - ARI), with specific mass of $3.10 \mathrm{~kg} / \mathrm{dm}^{3}$, which develops high strength in its first days. CPV - ARI has minimal addition in its composition (NBR 5733). The other cement used was pozzolanic Portland cement (CPIV), with specific mass of $2.90 \mathrm{~kg} / \mathrm{dm}^{3}$, with the addition of large amounts of pozzolan, developing lower initial strength (NBR 5736).

Table1 presents the chemical characterization of the cements used, the data provided by the manufacturer and the Brazilian standards' requirements.

Table 2 presents the physical characterization of the cements used, the data provided by the manufacturer and the requirements of the Brazilian standards. It was observed that the values of specific mass previously cited, and which were determined in a laboratory, are, as expected, similar to those informed by the manufacturer.

\subsubsection{Fine aggregate}

The fine aggregate used was quartz sand, with specific mass of $2.62 \mathrm{~g} / \mathrm{cm}^{3}$, as determined by NBR NM 52 , maximum characteristic dimension equal to $4.8 \mathrm{~mm}$ and fineness modulus of 2.4 , according to NBR NM248.

\subsubsection{Coarse aggregate}

The coarse aggregate used was crushed basalt stones, with spe- cific mass of $2.90 \mathrm{~g} / \mathrm{cm}^{3}$, as determined by NBR NM 53 (2003), maximum dimension equal to $25 \mathrm{~mm}$ and shape index equal to 2.66, as determined by NBR NM 248 (2003)and NBR 7809 (1983), respectively.

\subsubsection{Water}

The water used was potable water, available in the water supply network of the city of Porto Alegre, RS.

\subsubsection{Superplasticizer}

In order to maintain workability through time, a third generation polycarboxylate additive with specific mass of $1.087 \mathrm{~g} / \mathrm{cm}^{3}$ and 40 $\%$ solids content was used.

\subsection{Methodology}

Four independent variables (factors) were used. They are: type of cement, cracking age, unit mix proportion, compacting time. An experimental dosage was used with the natural aggregates, using the IPT/EPUSP (HELENE and TERZIAN, 1992) method. First, the mortar content of the concrete mix proportion was set at $53 \%$. Based on the mortar content, three concrete mixes were made at the proportions of 1:2.5, 1:4 e 1:5.5 (cement: aggregates) for each cement, i.e., six mix proportions. The mix proportions were made using a $120 \pm 20 \mathrm{~mm}$ slump as standard. Initially, the mixes were made without additives, hence the slump was adjusted by adding water. The mixtures and the water/cement ratios necessary to attain the slump are presented in table 3.

The concrete was mixed in a tumble mixer truck, with capacity for $250 \mathrm{~L}$. Each mix was executed only once, with the volume of material determined proportionally for $100 \mathrm{~kg}$ of coarse aggregate. The volume of dry material was maintained constant in all the mixes.

The materials were added to the mixer in the following order: coarse aggregate, approximately $1 / 3$ of the water in the recipe, cement, second third of the water, sand, and the water necessary to achieve a $120 \pm 20 \mathrm{~mm}$ slump. The cement to water addition time was designated asinitial time or zero. From the initial time, a standard protocol was adopted:20-minute cycles, where the mixer does not rotate/rests for 15 minutes, and then it is turned on for the 5 remaining minutes. These cycles were carried out from 20 minutes up to 360 minutes or 6 hours. During the resting periods, a humid cloth was placed over the mixer's mouth in order to minimize the evaporation of water from the mix.

Following the rest and tumble cycles of the mixture inside the mixer at the time intervals of $120,180,240,300$ and 360 minutes, the 
procedure adopted was to determine the slump of the mix. After a checking of the slump, the procedure was to re-establish the slump so that it was equal or higher than $120 \mathrm{~mm}$. This was done by incorporating a superplasticizer into the mix.

Once the intended slump was attained, for each mix produced three cylindrical test samples were cast, measuring $10 \mathrm{~cm}$ in diameter by $20 \mathrm{~cm}$ in height, as prescribed by NBR 5738/03 - concrete - procedure for casting and curing test samples to carry out compressive strength tests.

In view of the characteristics of the mix, test samples were cast at zero minutes, immediately after the homogenization of the mix, and at 120,180, 240, 300 and 360 minutes, i.e., every hour, starting at two hours.

After they were cast, the cylindrical test samples were covered with humid burlap bags and exposed to ambient temperature and humidity during 24 hours, thereafter they were demolded and taken to a tank filled with lime-saturated water, where they were submerged at a temperature of $23 \pm 2^{\circ} \mathrm{C}$, until one day prior to the testing date. On that day, the test samples were coated and taken to the compression test.

The compressive strength tests were carried out as prescribed by NBR 5739 - concrete -compression test of cylindrical test samples. They were executed using the servo controller machine Shimadzu $2.000 \mathrm{kN}$ at a tension application speed of $0.45 \mathrm{MPa} / \mathrm{s}$, maintained constant throughout the test. The test samples were coated with sulphur.

\section{Results and discussion}

The test samples were broken at 7 and 28 days after casting. The average of the results are shown on figures 2 to 5 . Figure 2 presents the average values obtained from 3 test samples, for the concretes produced with CP V ARI. In general, the average results obtained for the three mixes, at 7 days, were constant for the intermediary mix throughout the different casting times. However, for the bad mix, as well for the good mix, an increase in average resistance was verified over time, from the mixing until the casting. This fact can be attributed to the loss of water from the mixture to the environment, which decreases the actual water/cement ratio of the mixture, thus increasing resistance. Another possible explanation is the breaking of the first hydration products, which are larger and more fragile, and are subsequently replaced by smaller, more resistant crystals.

\section{Figure 2 - Compressive strength of the concrete} made with CPV-ARI, at seven days

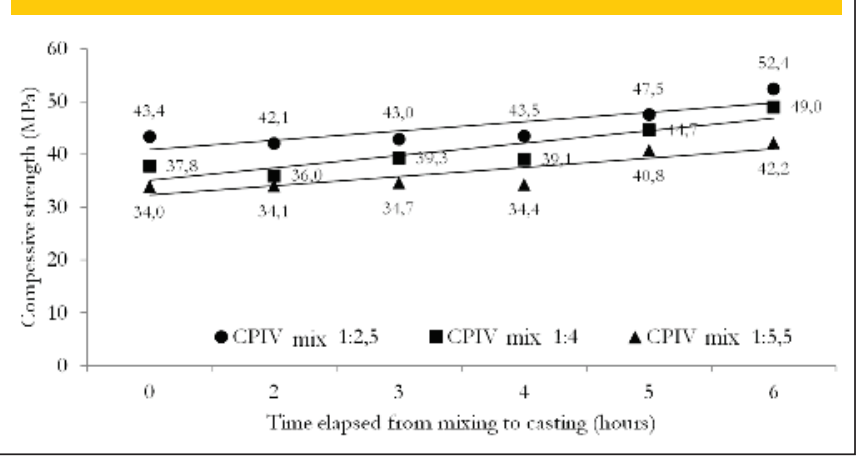

Figure 3 presents the average resistance of test samples produced with CPV-ARI and broken 28 days after casting. Generally, at this age, as shown in Figure 2, resistance increases as the time interval between mixing and casting increases. At 28 days, a significant increase occurs for the richer mix proportion, but the intermediary and the poorer mix also have their resistances increased.

Figure 4 presents the average resistance of the test samples cast with CPIV and broken 7 days after casting. For the CPIV cement, which presents a weaker resistance gain in the early ages, compared with CPV, the behaviour of the resistance, particularly for the richer mix proportion, was the maintenance of the resistance over the time elapsed until casting. However, for the poorer mix proportion the averages increase as the time elapsed until casting increases.

Figure 5 presents the average resistance for test samples cast with CPIV and broken at 28 days. A small increase in resistance is verified through the time interval between mixing and casting. Similarly to what is observed in Figure 4, the increase in resistance for the poor mix proportion is greater than for the others.

A variance analysis (ANOVA) was made using the individual values to check whether the analysed values are significant. Table 1 summarizes the parameters of the analysis of the experimental data collected in this study.

As expected, the variables type of cement, breaking age and mix proportion are significant, and their behaviour is widely consolidated in the current literature. The variable casting time, which is the time elapsed from the mixing of the materials until the casting, and which constitutes the object of this study, has also proven to be significant. The behaviour observed in figures 2 to 5 , however, show that compressive strength increases as the time interval until the casting increases. This observation is evidently only valid for the particular conditions through which the slump was maintained constant and which were proposed in the methodology of this study.

As previously mentioned, the observation of the increase in the average compression strength of concretes cast over a longer time may be explained by the loss of water to the environment and, consequently, a reduction in the actual water-cement ratio of the mix, as well as a possible breaking of the first hydration products formed, which are larger and more fragile. It is important to highlight that this increase can vary depending on the characteristics of the equipment used and the volume produced. Hence, it is necessary to investigate whether the same occurs

Figure 3 - Compressive strength at twenty eight days, made with CPV

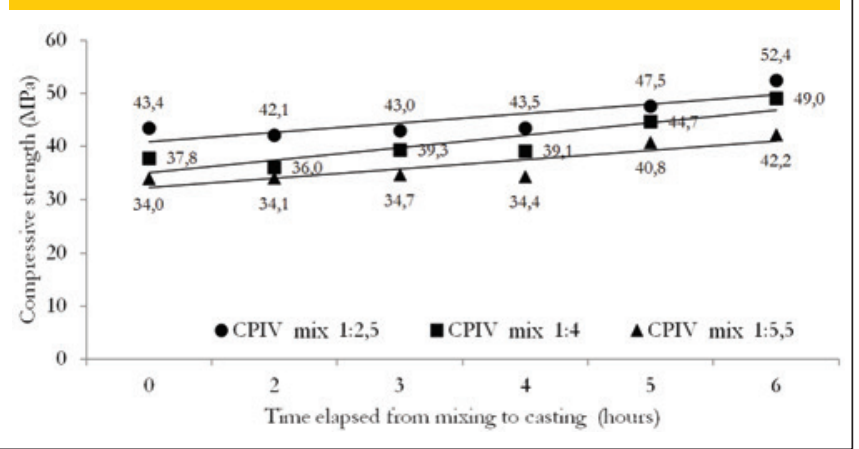




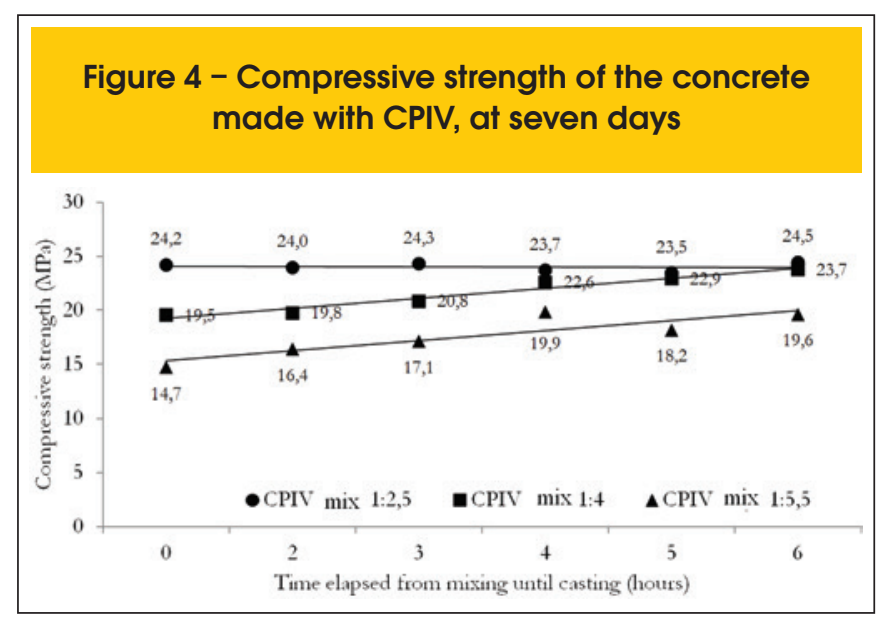

with other equipment and, especially, with a greater volume of concrete mixes.

However, it is important to emphasize that the employment of superplasticizers, along with regular agitation, allowed the casting of the concrete to be done over a time interval 2.5 times longer than what is prescribed by NBR 7212 , while maintaining its mechanic performance.
Figure 5 - Compressive strength of concrete at twenty eight days, made with CP IV

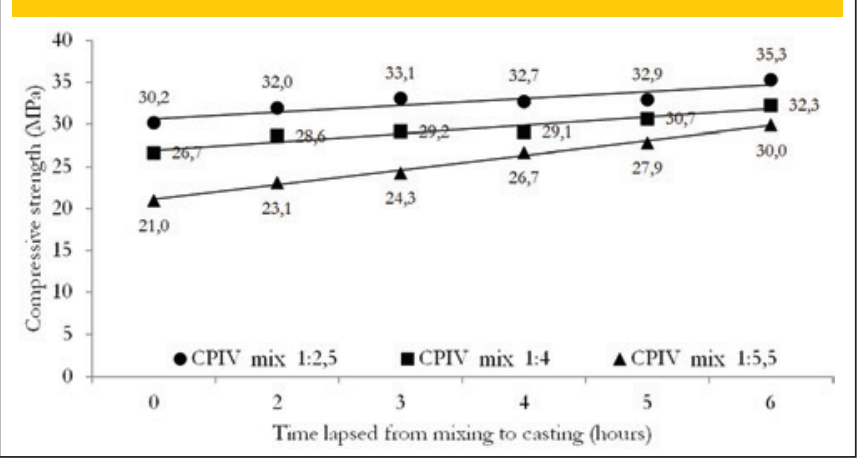

\section{Conclusions}

This study shows that differently from the standards set by NBR 7212 and from what is widely indicated in the literature, the concrete casting and finishing time can be extended beyond $150 \mathrm{~min}$, to up to $360 \mathrm{~min}$, as long as slump is maintained through the use of superplasticizers (maintaining the water/

\section{Table 4 - Variance analysis}

\begin{tabular}{|c|c|c|c|c|c|c|}
\hline \multirow{2}{*}{ Source } & \multicolumn{6}{|c|}{ Test } \\
\hline & SQ & GDL & $\mathbf{M Q}$ & $\mathbf{F}$ & Probab & Comment \\
\hline A: Type of cement & 8780.53 & 1 & 8780.53 & 519,32 & $0.00 \%$ & $s$ \\
\hline B: Breaking age & 2787.30 & 1 & 2787.30 & 164,85 & $0.00 \%$ & $S$ \\
\hline C: Compacting time & 1056.91 & 5 & 211.38 & 12.50 & $0.00 \%$ & $S$ \\
\hline D: Mix proportion & 1792.62 & 2 & 896.31 & 53.01 & $0.00 \%$ & $S$ \\
\hline$A B$ & 24.48 & 1 & 24.48 & 1.45 & 23.09 & NS \\
\hline$A C$ & 258.96 & 5 & 51.79 & 3.06 & $1.18 \%$ & $\mathrm{~s}$ \\
\hline$A D$ & 262.74 & 2 & 131.37 & 7.77 & $0.06 \%$ & $S$ \\
\hline$B C$ & 146.57 & 5 & 29.31 & 1.73 & $13.09 \%$ & NS \\
\hline BD & 77.52 & 2 & 38.76 & 2.29 & $10.49 \%$ & NS \\
\hline$C D$ & 241.03 & 10 & 24.10 & 1.43 & $17.52 \%$ & NS \\
\hline$A B C$ & 65.99 & 5 & 13.20 & 0.78 & $56.54 \%$ & NS \\
\hline$A B D$ & 108.75 & 2 & 54.37 & 3.22 & $4.32 \%$ & $\mathrm{~s}$ \\
\hline$A C D$ & 406.53 & 10 & 40.65 & 2.40 & $1.16 \%$ & $\mathrm{~s}$ \\
\hline BCD & 414.57 & 10 & 41.46 & 2.45 & $1.00 \%$ & $\mathrm{~s}$ \\
\hline$A B C D$ & 284.74 & 10 & 28.47 & 1.68 & $9.03 \%$ & NS \\
\hline Error & 2316.35 & 137 & 16.91 & - & - & - \\
\hline Total & 19025.58 & 208 & - & - & - & - \\
\hline
\end{tabular}


cement ratio), without loss of compressive strength.

\section{Acknowledgments}

The authors would like to thank NORIE (Núcleo Orientado à Inovação da Edificação), UFRGS, for their support in the experimental phase of this study and the Coordenação de Aperfeiçoamento de Pessoal de Nível Superior (CAPES) for providing funding for this study.

\section{References}

[01] ASSOCIAÇÃO BRASILEIRA DE NORMAS TÉCNICAS. NBR NM 52: Agregado miúdo - Determinação da massa específica aparente. Rio de Janeiro: ABNT, 2003.

[02] _. NBR NM 53: Agregado graúdo - Determinação da massa específica, massa específica aparente e absorção de água. Rio de Janeiro: ABNT, 2003.

[03] _. NBR NM 65: Cimento Portland - Determinação dos tempos de pega - método de ensaio. Rio de Janeiro: ABNT, 2002.

[04] __. NBR NM 67: Concreto - Determinação da consistência pelo abatimento do tronco de cone. Rio de Janeiro: ABNT, 1998.

[05] _... NBR NM 248: Agregados - Determinação da composição granulométrica. Rio de Janeiro: ABNT, 2003.

[06] _. NBR 5733: Cimento Portland - Cimento Portland de alta resistência inicial - especificação. Rio de Janeiro: ABNT, 1991.

[07] __. NBR 5735: Cimento Portland - Cimento Portland de alto-forno - especificação. Rio de Janeiro: ABNT, 1991.

[08] _. NBR 5736: Agregados - Determinação da composição granulométrica. Rio de Janeiro: ABNT, 2003.

[09] __. NBR 5738: Concreto - Procedimento para moldagem e cura de corpos-de-prova. Rio de Janeiro: ABNT, 2003.

[10] _. NBR 5739: Concreto - Ensaio de compressão de corpos-de-prova. Rio de Janeiro: ABNT, 1994.

[11] _. NBR 7112: Concreto - Execução de concreto dosado em central. Rio de Janeiro: ABNT, 1984.

[12] _. NBR 11578: Agregados - Determinação da composição granulométrica. Rio de Janeiro: ABNT, 2003.

[13] HELENE, P. L.; TERZIAN, P. R. Manual de dosagem e controle do concreto. Brasília: Pini, 1992.

[14] MEHTA, P. K.; MONTEIRO, P. J. M. Concreto: estrutura, propriedades e materiais. São Paulo: IBRACON, 2008.

[15] NEVILLE, A. M. Propriedades do concreto. $2^{\circ}$ ed. São Paulo: PINI, 1997.

[16] SILVA, E. F. Variações dimensionais em concreto de alto desempenho contendo aditivo redutor de retração. 2007. Tese (Doutorado em Ciências em Engenharia Civil) - Programa de Pós-Graduação em Engenharia, Universidade Federal do Rio de Janeiro, Rio de Janeiro.
[17] VIEIRA, G. L. Influência da microfissuração causada por carregamento precoce nas propriedades mecânicas de concretos produzidos com diferentes tipos de cimento. 2008. Tese (Doutorado em Engenharia Civil) - Programa de Pós-Graduação em Engenharia Civil, Universidade Federal do Rio Grande do Sul, Porto Alegre. 